\title{
GROWTH AND TRADE OF FOOD, SPICES AND MEDICINES IN AN AFRICAN COASTAL CITY: ACCRA, GHANA
}

\author{
ISABEL MARIA MADALENO \\ Institute of Geography and Spatial Planning (IGOT), Universidade de Lisboa, Portugal
}

\begin{abstract}
The Gold Coast was first discovered by the Portuguese Pedro de Santarém and Pedro Escobar in 1471. Two years earlier, in 1469, the trade in the Gulf of Guinea had been leased to a wealthy Lisbon trader by King Afonso V, under the obligation to navigate further south to Sierra Leone in order to spread both the Christian faith and increase the empire. This paper starts with the examination of two 16th century manuscripts, by Damião de Góis (1567) and Garcia de Resende, where the first African palm trees, such as Elaeis guineensis, and spices like Amomum melegueta were mentioned. The methodology proposed also includes a survey of flora consumption in Accra, Ghana, formerly known as the Gold Coast, independent from Britain in 1957. The cross-examination of the cultivated and traded species will determine the results, aiming to compare the useful flora and their uses during European expansion and in contemporaneity. Results prove that the African spice mentioned in the manuscripts was replaced by Capsicum annuum and chinense, but palm fruits are still smashed and consumed in stews; the seed is used to make oil and the flower is burned to smoke away undesirable mosquitoes. These insects can transmit such diseases as malaria, for which poor people drink boiled leaves of pawpaw (Carica papaya) and Moringa citrifolia to ease fever. A total of 101 plant species were recorded in 2018, mostly used as food. The hope is to contribute to a better understanding of the evolution of flora consumption in Africa, initiated by this scientific mission of the University of Lisbon to Ghana. A second objective is to present the trend to increase the wellbeing of urban residents in Accra.
\end{abstract}

Keywords: Accra, food, medicines, wellbeing.

\section{INTRODUCTION}

Sustainable development as defined in "Our Common Future", the so-called Brundtland Report [1], establishes a cause-effect relationship between the economy and the environment. However, the social and cultural dimensions of the concept defined in 1987 cannot be forgotten, because poverty eradication is closely "linked to ecological integrity and vice-versa" [2]. According to Griggs et al. [3], only fully functioning Earth Systems can contribute to create sustainability for a global society. Under that assumption they propose a new sustainable development definition, as follows: "Development that meets the needs of the present while safeguarding Earth's life-support system, on which the welfare of current and future generations depends" [3, p. 306].

This contribution is part of a project aimed at answering the question: Was flora consumption sustainable in Ghana, from the beginning of Portuguese colonisation to our days? In order to find responses the methodological approach was threefold, starting with the examination of two Renaissance manuscripts, followed by a scientific mission to Ghana, aimed at conducting a survey to useful flora consumption in our days, intended to evaluate the sustainability of native plant species through times. The structure of the paper, after this introduction, plus the geographical location and methodology, will include the discussion of the results gathered in Accra, illustrated with a table and photos, towards a conclusion. 


\section{GEOGRAPHICAL LOCATION}

Located in the Gulf of Guinea, at $5^{\circ} 33^{\prime}$ North of the Equator, Accra is a coastal city that was an important Portuguese trading post in Africa for 155 years [4]. It has a tropical environment that registers 806.8 millimetres of rainfall per annum [5]. Ghana is the second largest world producer of cocoa, currently registering an annual $8.3 \%$ growth rate. In spite of this number, it has high poverty levels, the statistics fail to compile. The enormous amount of youngsters and females, at any age level, that trade on the streets of Accra are a good indicator of the informality of the economy [6]. Independent from 1957 onwards, the country is rich in mineral resources, such as gold, silver, oil, diamonds, bauxite, and manganese; the over 28 million inhabitants Ghana is also an agriculture oasis for tropical plant species of any kind (see map in Fig. 1).

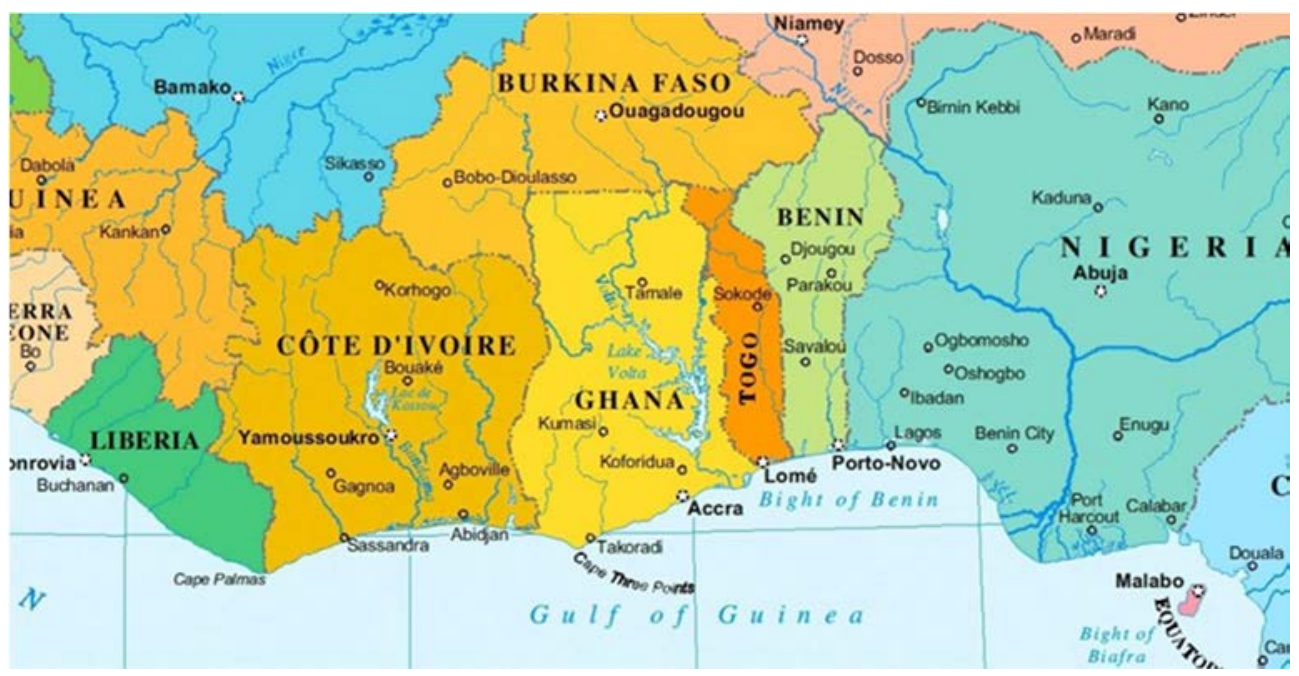

Figure 1: Location of Ghana in the Gulf of Guinea. (Source: Rad-Aid.Org, 2019: https://www.rad-aid.org/countries/africa/ghana/.)

\section{OBJECTIVES AND METHODOLOGY}

The food, spices and medicines growth and trade project focusing African countries, currently developed in the University of Lisbon, has two main aims: 1) to contribute for a better understanding of the evolution of flora consumption; and 2) to present a trend of good practises to be explored, in order to increase the wellbeing of Ghanaian urban residents. In fact, all useful flora is under scrutiny because, as was the case with previous similar studies developed in Latin America [7] and Asia [8], as a researcher of the Tropical Institute, plant species used as natural remedies are very numerous in the gardens, peri-urban farms, and in local markets.

The methodology follows the path established in the previous research projects, which is essential to make results comparable worldwide. There were three phases in the process, as mentioned: 1) Examination of 16th century manuscripts, by de Goes [9] and de Resende [10], two chronicle writers sponsored by Portuguese King John III; and 2) Investigation of the current uses of flora in Accra, Ghana, conducted during a scientific mission, in the year 2018, aimed at gathering in-depth interviews to three categories of informants: a) food, spices and 
medicines growers; b) raw, cooked food and spices traders, as well as herbal remedies sellers; c) service providers, with a touristic guide status.

The survey totalled 50 respondents. 3) Last, but not least, the botanical identification of all flora mentioned in the manuscripts, and collected during fieldwork, was the following procedure, so as to permit the cross-examination of data, both through times and across the world, using the Missouri Botanical Garden and the Natural Biodiversity Institute norms, easily available online [11], [12]. The results gathered during this first mission to Africa have already been presented to an urban planning and architecture conference in Italy [6].

\section{RESULTS AND DISCUSSION}

Accra's urban area provides various goods and services, mostly in an informal way, as said. Physical spaces obviously include formal trading posts, yet it is impossible to explore the city without noticing the big array of people, mostly women that sell all kinds of fruits, such as bananas (12 occurrences), lemon sleeve (Citrus medica) or peanuts (5 occurrences) on the traffic lights or on the sidewalks. Urban and peri-urban green environments also provide food, spices and medicines, as well as shade, oxygen and infiltration spaces that reduce storm water impacts. However, the Ghanaian project was focused mainly on food traded in the capital city, in markets, supermarkets, and informal locations, as the gardeners interviewed were only two, while traders totalled forty-six.

"Urban food security refers to the access to, availability of, and use of food" [13]. Low income families and workers from Accra frequently eat street food cooked or brought to the sidewalks, traded even along the roads that connect the capital city to peri-urban areas or other urban environments, as is the case with Elmina historic site. Raw food is also traded along the roads, together with all sorts of goods (see Fig. 2). Elmina is a town located in Ghana's Central Region. About $75 \%$ of the residents are engaged in fishing and fishing related businesses there [4]. But the site is mostly known for the Portuguese St George Castle [10], built just eleven years after the discovery (1482), when Diogo de Azambuja supervised its construction (see photo in Fig. 3).

The so-called Elmina Castle, a corruption of the Portuguese word mine, was supposed to become a trading post for gold, but sadly it became a famous slave exporting spot to Europe first, and to the Americas soon after. In 1637 the Dutch took control of the dungeons, and continued the trans-Atlantic slave trade. Following slavery abolition in 1814, the castle exploitation became unprofitable and thus the Dutch sold it to the British, in 1872. According to Dresh (1946), Ghana's economy is still export-oriented, and has had three different trade cycles: 1) the early European gold and slave trade phase; 2) the 19th century palm oil, cocoa, coffee, peanuts and shea butter cycle; and 3) the 20th century oil, diamonds, aluminum, magnesium and, again, gold trade export cycle [14].

Ghana registers a logical continuity in governmental policies, which trend is export oriented in the 21 st century. Regarding Accra, the green spaces the city possesses contribute to increase the quality of the environment, a fundamental issue nowadays, as said. As Simon et al. wrote: "The connections between urbanization and the GECs", meaning the global environmental change, challenge urban planning experts to adapt the cities to new risks [15]. The Brazilian Neli Mello-Théri added that the paradox lies on the dual role of humankind. We are all responsible for the environmental stresses that turned against us, but as intelligent creatures, having memory and learning capabilities, we are also able to resolve the problems provoked by our overexploitation of natural resources, producing new technologies that might mitigate natural catastrophes [16]. 


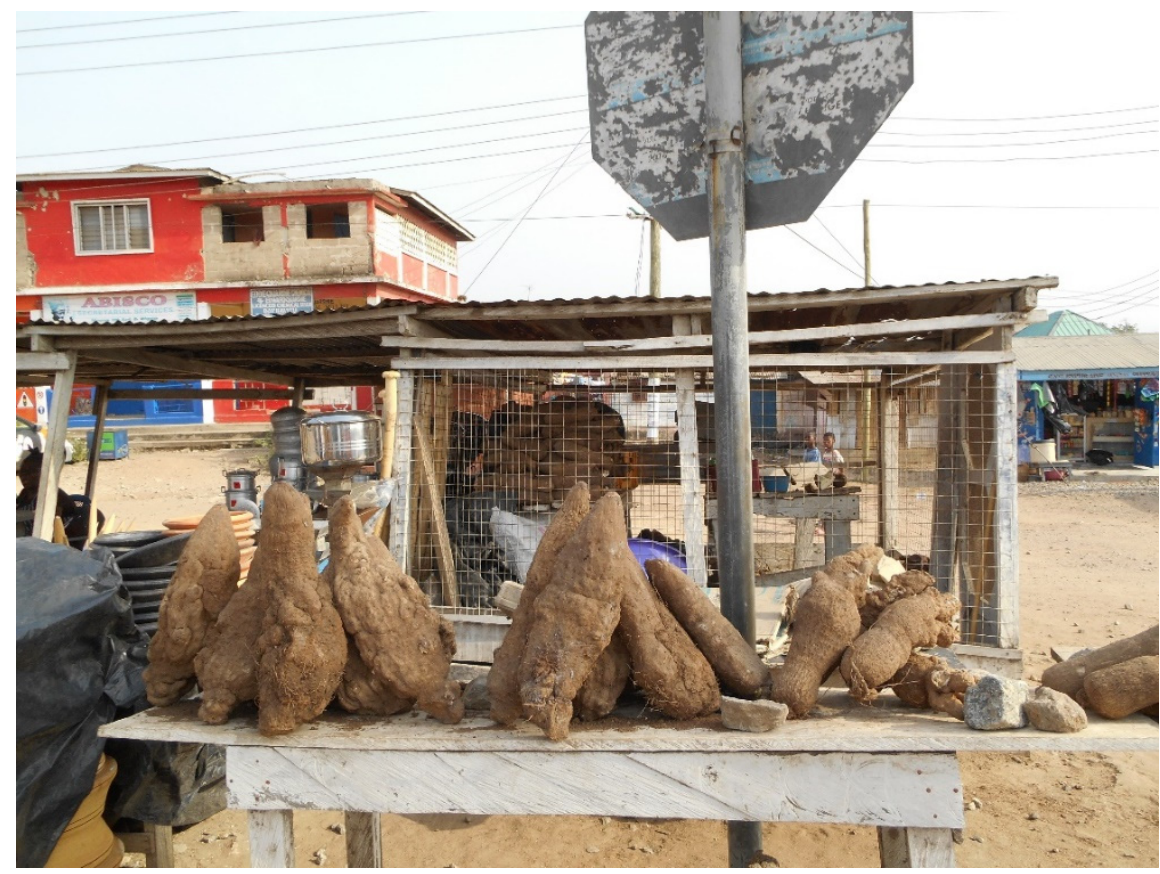

Figure 2: Local Yam (Dioscorea rotundata) sold on the route to Elmina Castle. (Source: Author's photo, 2018.)

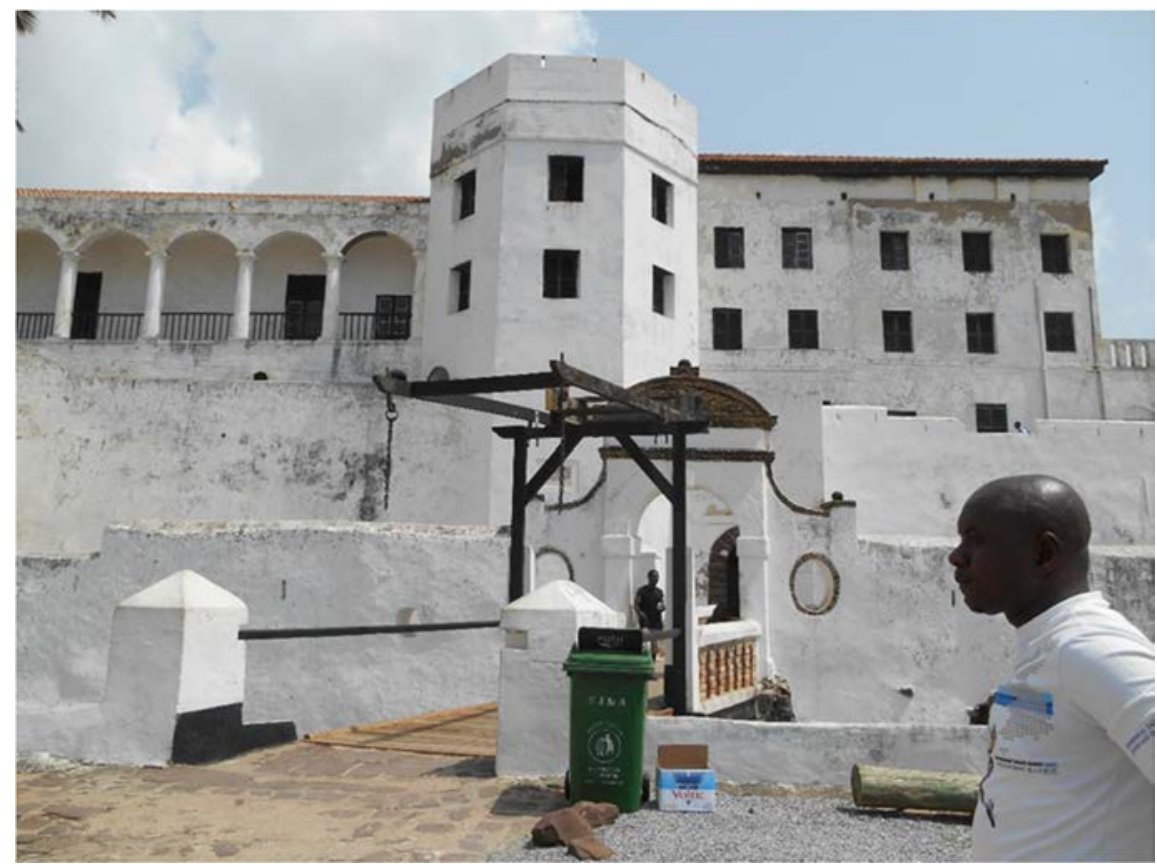

Figure 3: St. George Castle, in the so-called Elmina site. (Source: Author's photo, 2018.) 
This contribution is not focused on urban agriculture, seen as one of the strategies designed to cope with the challenges posed by climate change, instead it introduces a new informant, absent from previous research projects, the Aburi Botanic Gardens. Formerly a pulmonary disease hospital, located on higher altitudes, near Accra, it was a biodiversity and oxygen producer location used to cure wealthy residents by the end of the 19th (1895) and in the beginning of the 20th century. It is now a botanical garden aimed at educating Ghanaians on ecological sciences, but it is also used to show how plant diversity can improve the health and the wealth of the citizens. The garden is therefore used to give Ghanaians best examples on how to solve the environmental challenges posed by the new climate change risks.

\subsection{Food and spices grown and traded now and in the 16th century}

Flora mentioned in both manuscripts examined totalled twenty-three [9], [10]. Only a couple is of interest to Ghana, namely the African Chilli (Amomum melegueta) and the African palm (Elaeis guineensis). Whereas this last plant species, the oil palm, has registered six occurrences, in contemporaneity, the traditional African spice has been replaced by the American chilli (Capsicum annuum), again with 6 reports, in the 2018 survey of the University of Lisbon (see Fig. 4). Table 1 presents the results, as far as the food species and spices are concerned. The survey totalled 101 plant species in Ghana. About fifty-eight $(57.43 \%)$ were consumed as food; nine as spices $(8.9 \%)$.

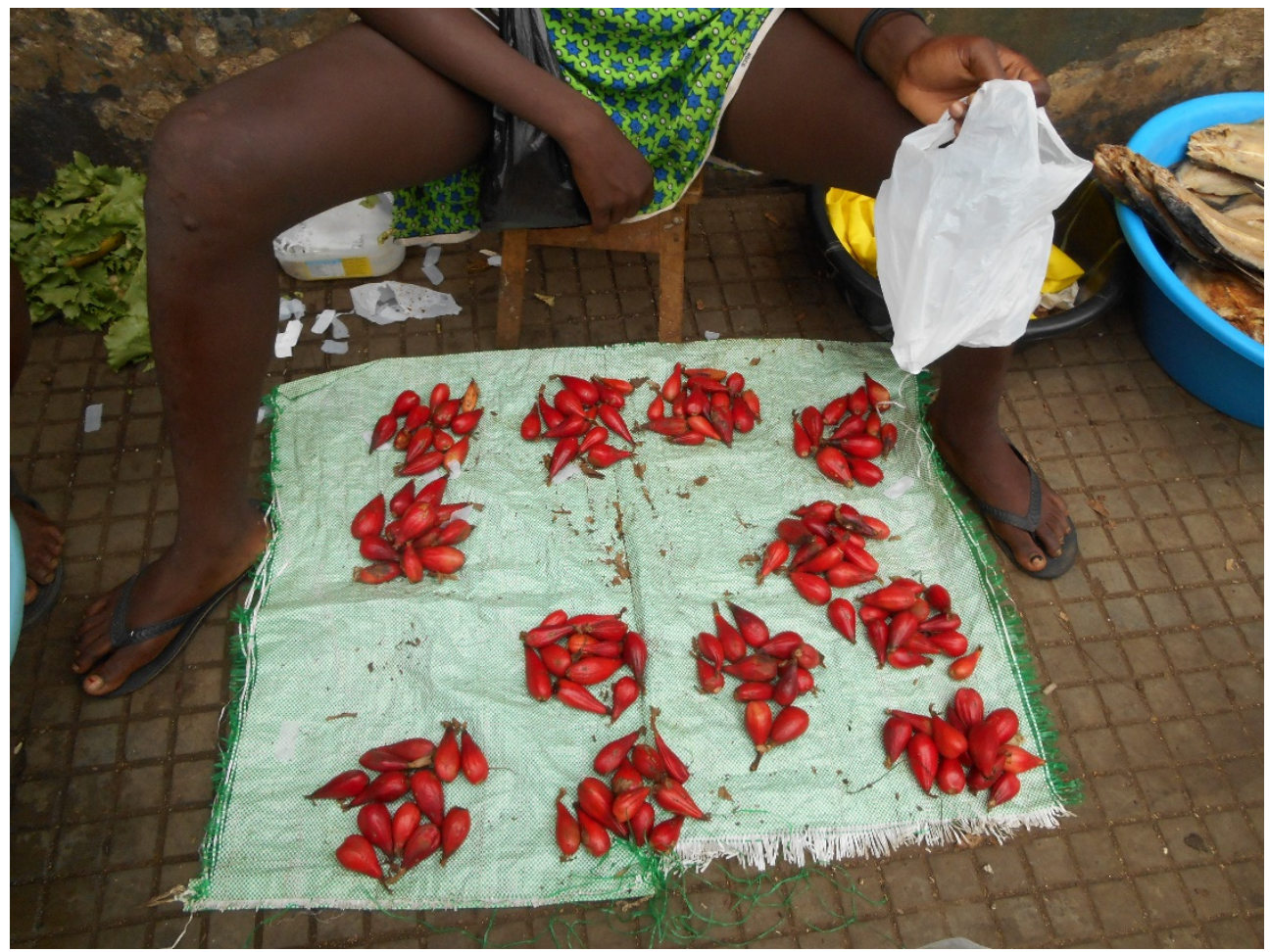

Figure 4: Amomum melegueta, the African spice of the 16th century manuscripts. (Source: Author's photo, S. Tomé, 2019.) 
Table 1: Food and spices traded and grown in Ghana, in the 16th century and today. (Source: Author, 2018.)

\begin{tabular}{|c|c|c|c|}
\hline Common names & Botanical names & $\begin{array}{c}\text { No. of } \\
\text { occurrences }\end{array}$ & $\begin{array}{c}\text { Manuscripts } \\
\text { mentioned }\end{array}$ \\
\hline African chilli & $\begin{array}{l}\text { Amomum melegueta Roscoe } \\
\text { ZINGIBERACEAE }\end{array}$ & 1 & [9], [10] \\
\hline Banana & $\begin{array}{l}\text { Musa paradisiaca L. } \\
\text { MUSACEAE }\end{array}$ & 12 & - \\
\hline $\begin{array}{l}\text { Cauliflower, } \\
\text { cabbage, kale }\end{array}$ & $\begin{array}{l}\text { Brassica oleraceae L. } \\
\text { BRASSICACEAE }\end{array}$ & 8 & - \\
\hline Cocoa & $\begin{array}{l}\text { Theobroma cacao L. } \\
\text { MALVACEAE }\end{array}$ & 9 & - \\
\hline Coconut & $\begin{array}{l}\text { Cocos nucifera L. } \\
\text { ARECACEAE }\end{array}$ & 7 & - \\
\hline Ginger & $\begin{array}{l}\text { Zingiber officinale Roscoe } \\
\text { ZINGIBERACEAE }\end{array}$ & 7 & - \\
\hline Melon & $\begin{array}{l}\text { Cucumis melo L. } \\
\text { CUCURBITACEAE }\end{array}$ & 6 & - \\
\hline $\begin{array}{l}\text { Palm seeds, } \\
\text { African palm }\end{array}$ & $\begin{array}{l}\text { Elaeis guineensis Jacq. } \\
\text { ARECACEAE }\end{array}$ & 6 & {$[10]$} \\
\hline $\begin{array}{l}\text { Peppers, chilli } \\
\text { pepper }\end{array}$ & $\begin{array}{l}\text { Capsicum annuum L. } \\
\text { SOLANACEAE }\end{array}$ & 6 & - \\
\hline Yam & $\begin{array}{l}\text { Dioscorea rotundata Poir. } \\
\text { DIOSCOREACEAE }\end{array}$ & 7 & - \\
\hline
\end{tabular}

In spite of the less frequent use of the African pepper in 2018, the spice was so precious in the beginning of Portuguese colonisation that, in 1471, King Afonso V, signed a law where he declared Amomum melegueta to become a royal monopoly [9]. Because the Portuguese navigator Pedro Álvares Cabral officially discovered Brazil, in 1500, the American chilli pepper was soon introduced in the Gold Coast, now Ghana, as well as other delicacies, such as cocoa (Theobroma cacao). The same process happened with ginger, a spice brought by navigators, following Vasco da Gama discovery of the maritime route to India, in 1498. Spices are not as vital to preserve food in our days, yet they are very much sought after to flavour all sorts of dishes, in Accra. Local yam usually accompanies fish and meat (see Fig. 2).

Table 1 presents 10 plant species gathered during the survey, of which only the first has a unique collection. The remainder nine are the top-ranking occurrences in Accra, Ghana, during the 2018 survey. As observed, about one third of these flora specimens are spices, whereas four are fruits. As to the geographical origin, besides the palm seeds and the African spice, the yam is also a native plant. This gives good ground for the project's purposes, meaning the evaluation of the preservation of local biodiversity and the record of the variety of exotic flora consumed in modernity, mostly introduced during the colonisation process that contributes for families' nutrition and wellbeing.

The Ghanaian Ato Ashun [4], wrote that "when a child is born in Ghana, the elders wait for seven days and, if the new-born doesn't return to the ancestors, a naming ceremony is then started. In order for the mother to have enough breast milk for the child, several foods are especially served to her, such as: yam, banana, palm nuts, tomatoes and onions. The palm 
oil and the yam are items used in puberty rites, both for boys and girls, in the Elmina Heritage Site" [6, p. 62]. Exotic imports, as tomatoes (Solanum lycopersicum) and onions (Allium cepa and fistulosum), both with 5 occurrences, are now part of Ghanaian culture. Banana is the top-ranking food species, which is remarkable.

But the most precious exotic plant species for the Ghanaians is cocoa. There is a scientific research institute established in the Eastern region of the country, at Tafo, where investigations are conducted about such issues as pests and diseases control, as well as "to develop techniques for processing cocoa, coffee (...) and cashew with the view of improving cocoa production (...)", and aimed at developing "ways of using cocoa by-products to produce Alcohol and alcoholic beverages, cosmetics, soap and animal feeds" [17]. Cosmetics are equally important, both for local consumption and as export-oriented products. It is, again, in the eastern Region that research into plant medicine is conducted, in the Mampong Centre for Research [17], which leads us to the discussion of the next project result.

\subsection{Natural remedies used in Ghana}

About one third of the 101 plant species recorded during the scientific mission to Ghana (thirty-four) were medicinal plants or flora with cosmetic applications. As an example, the native palm seeds (Elaeis guineensis) were pressed to manufacture oil used to cook local dishes, but they were also crushed and boiled in a sort of stews (see Fig. 5). However, the flower was lighted up inside the houses, in order to smoke away the mosquitoes that transmit undesirable diseases, such as yellow fever or malaria, against which the Ghanaians boil pawpaw leaves (Carica papaya) and moringa (Moringa oleifera). Local species are also applied, as the African quinino, which leaves are boiled and ingested to ease fever.

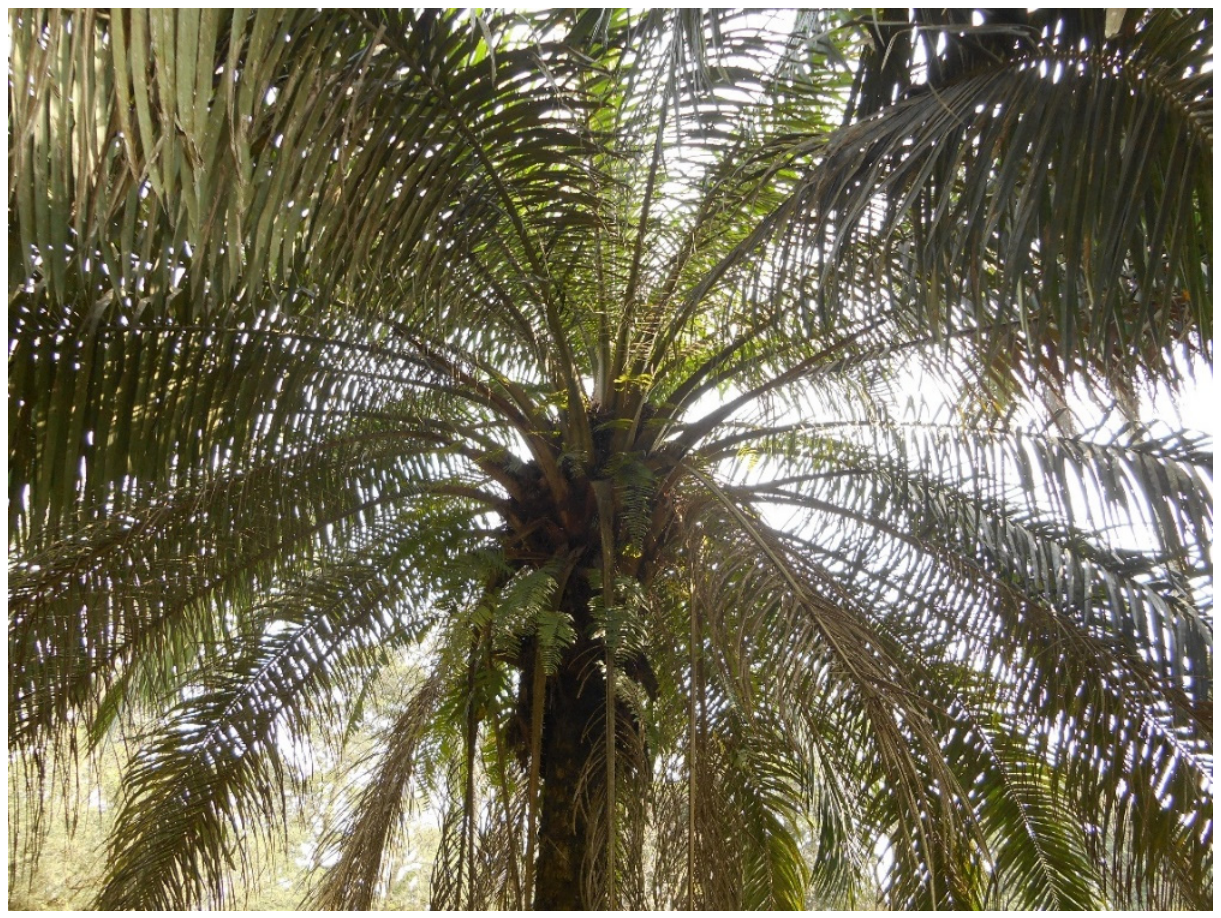

Figure 5: Elaeis guineensis, the Palm that gives oil. (Source: Author's photo, 2018.) 
Most flora reported dual usages, as is also the case with shea butter (Vitellaria paradoxa): the fruit is eaten raw; it also gives a very much appreciated butter (Karité), used to manufacture cosmetic products. Ghanaian women frequently constitute associations and small businesses, aimed at producing the valuable butter oil and sell it directly to tourists. We found that activity during the exploration of the Aburi Botanic Gardens, a place where in the previous two centuries patients were treated of such diseases as tuberculosis (see Figs 6 and 7). The gardens are now open for tourists, school students and locals, and they constitute an exploration site aimed at educating on ways to deal with current environmental challenges. They are about one hour away from Accra.

It is worth of mention the exotic medicinal flora recorded during fieldwork, as the Asian mace and nutmeg (Myristica fragrans). Mace is macerated in alcohol for 2 or 3 days, then cooked and drank to lower blood pressure. The nutmeg is crushed and added to milk, in order to give a restful sleep. Another plant species worth to be mentioned is the cinnamon tree (Cinnamomum zeylanicum), which bark is boiled to wash the eyes, to permit a good eyesight. It is consumed as spice, either. The most noticeable application was related with a Rutaceae, lemon sleeve (Citrus medica), which fruit was sold in traffic lights and in the markets, so as to be applied as a disinfectant, in the sanitary installations and bathrooms, in general.

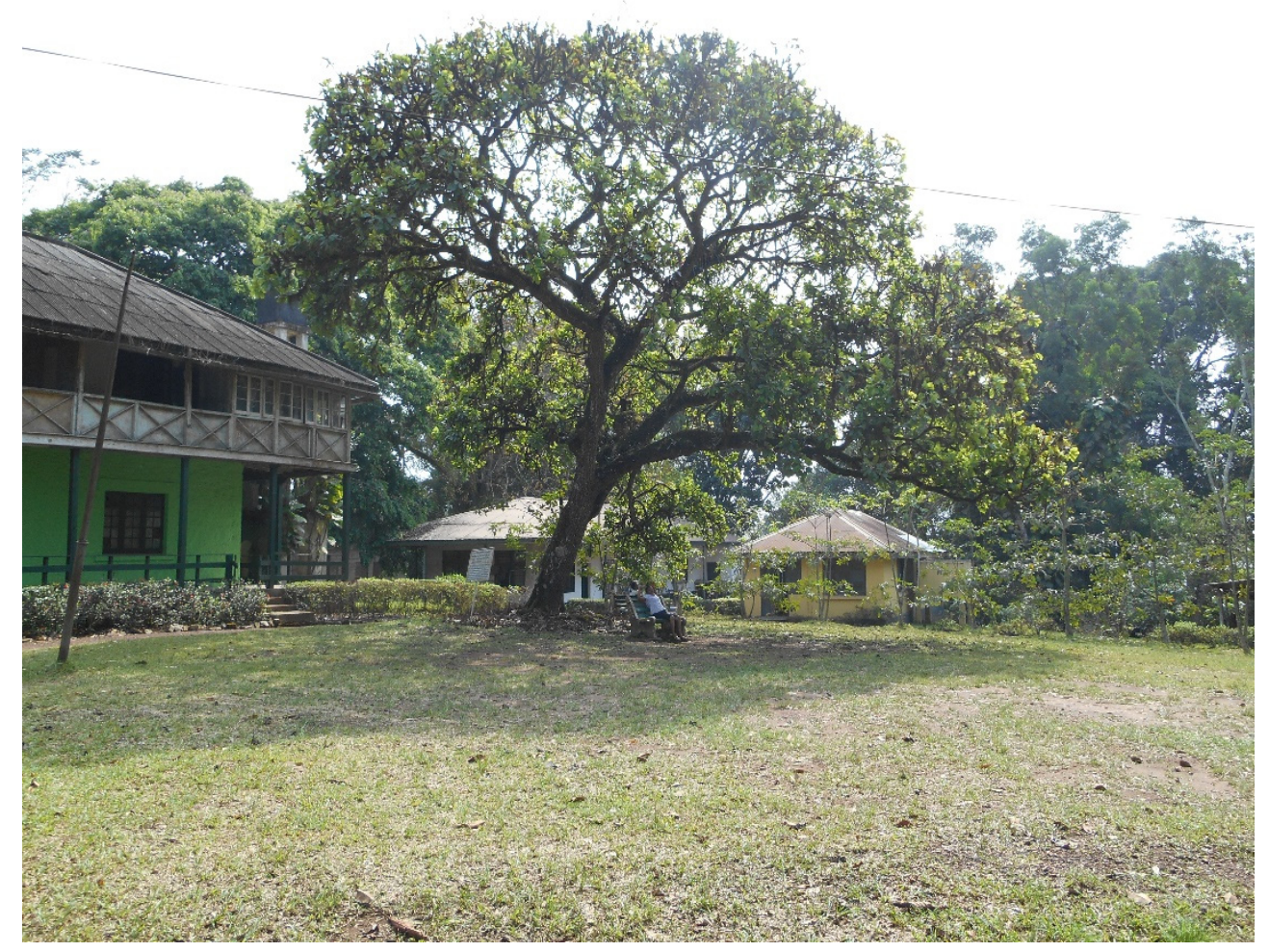

Figure 6: Shea Butter tree (Vitellaria paradoxa). (Source: Author's photo, 2018.) 


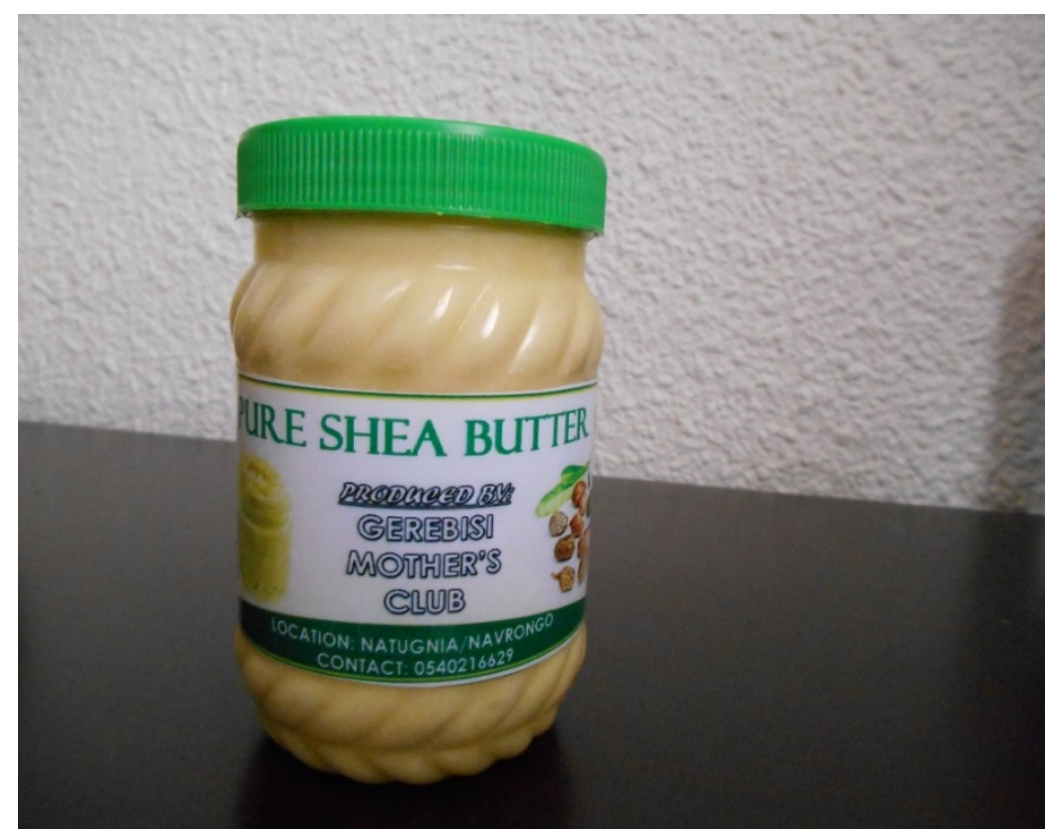

Figure 7: Shea Butter traded in the Aburi Botanic Gardens. (Source: Author's photo, 2018.)

\section{CONCLUSIONS}

So, was flora consumption sustainable in Ghana, from the beginning of Portuguese colonisation to our days? The answer to the research question is yes, even though only two plant species mentioned in the 16th century manuscripts examined were Ghanaian. The Coast of Gold was highly exploited during European colonisation, as the paper proves. To the current sustainable development evaluation, the second export-oriented phase of the economy, meaning, the 19th century monoculture farming cycle should be the target. Palm oil trees (Elaeis guineensis) are native species, as African is also the shea butter (Vitellaria paradoxa). Therefore, the cocoa and coffee beans cultivation is the issue here, as its cultivation gave way to the depredation of primary forests, and its replacement by secondary tracts of forests, bushes and savannas, along the coastline.

Meanwhile, there wasn't a heavy environmental challenge posed to the capital city, Accra, because the Volta river provides enough water to the urban coastal areas (see map in Fig. 1). Accra has over one million and a half inhabitants, these days. Natural medicines are mostly used by low-income populations, as is the gardening of food species and spices. The poorest lack access to primary healthcare assistance, though, a frequent problem in Africa. Yet, research results found no evidence of concerns about food security in the capital city of Ghana.

\section{ACKNOWLEDGEMENTS}

Thanks are due to all informants for their availability to share food habits and medicinal remedy applications during the scientific mission to Ghana. Thanks are also due to anonymous reviewers of the paper presented to the Italian conference $-11^{\circ}$ Inu Study Day in Naples, 2018. 


\section{REFERENCES}

[1] Report of the World Commission on Environment and Development. Our Common Future; United Nations General Assembly https://sswm.info/sites/default/files/ reference_attachments/UN\%20WCED\%201987\%20Brundtland\%20Report.pdf. Accessed on: 31 Jan. 2019.

[2] Chaigneau, T., Coulthard, S., Brown, K., Daw, T.M. \& Schulte-Herbruggen, B., Incorporating basic needs to reconcile poverty and ecosystem services. Conservation Biology, 0, pp. 1-10, 2018.

[3] Griggs, D. et al., Sustainable development goals for people and planet. Nature, 495, pp. 305-307, 2013.

[4] Ashun, A., Elmina, the Castles and the Slave Trade, Nyakod Printing \& Publishing: Cape Coast, 2017.

[5] WMO, Climate Data for Accra (1961-1990). https://public.wmo.int/en. Accessed on: 15 Feb. 2019.

[6] Madaleno, I.M., Flora consumed in Accra, Ghana, in the 16th century and today. Urbanistica Informazione, XXXXV(278), pp. 61-63, 2018.

[7] Madaleno, I., Medicinal flora and the Jesuits in Latin America (XVI-XVII). Archivum Historicum Societatis Iesu, LXXXIV(167), pp. 111-147, 2015.

[8] Madaleno, I.M., Traditional medicinal knowledge in India and Malaysia. Pharmacognosy Communications, 5(2), pp. 116-129, 2015.

[9] de Goes, D., Chronica do Principe D. Joam, Rey que Foy destes Reynos, Segundo do Nome, em que sumariamente se trataõ as cousas substanciaes, que neles aconteceraõ do dia de seu nascimento até o em que El Rey D. Affonso seu Pay faleceo, Francisco Correia Impressor: Lisboa, 1567.

[10] de Resende, G., Chronica dos Valerosos e Insignes Feytos del Rey Dom Joam II. De Gloriosa Memoria, em que se refere a sua vida, suas virtudes, seu magnânimo esforço, excellentes costumes, \& seu cristianíssimo zelo. Officina Manoel da Sylva: Lisboa (5th ed.), 1770.

[11] MBG, Plant Identification. Missouri Botanical Garden. www.tropicos.org. Accessed on: 17 Feb. 2019.

[12] NBI, National Biodiversity Institute. http://pza.sanbi.org/aspalathus-linearis. Accessed on: 18 Feb. 2019.

[13] Gatzweiler, F.W., Boufford, J.I. \& Pomykala, A., Harness urban complexity for health and well-being. The Urban Planet, eds T. Elmqvist et al., Cambridge University Press: Cambridge, p. 121, 2018.

[14] Dresh, J., Sur une Géographie des Investissements de Capitaux. L'Exemple de l'Afrique Noire. Bulletin de l'Association de Géographes Français, 177-178, pp. 5964, 1946.

[15] Simon, D., Griffith, C. \& Nagendra, H., Rethinking urban sustainability and resilience. The Urban Planet, eds T. Elmqvist et al., Cambridge University Press: Cambridge, p. 155, 2018.

[16] Mello-Théry, N.A., Ambiente, Desenvolvimento e Políticas de Biodiversidade (Brasil). Finisterra, LIII(109), pp. 133-148, 2018.

[17] Agodoa, R., Regional Tourist Maps of Ghana, Rose Tourist Centre: Accra, p. 12, 2012. 